\title{
AKULTURASI BUDAYA MAHASISWA DALAM PERGAULAN SOSIAL DI KAMPUS (Studi Kasus Pada Mahasiswa PGSD UPP TEGAL FIP UNNES)
}

\section{Tri Astuti}

PGSD UPP Tegal FIP Universitas Negeri Semarang

\section{Info Artikel Abstract}

Sejarah Artikel:

Diterima 28 Sept 2017

Disetujui 24 Nov 2017

Dipublikasikan Des 2017

\section{Keywords:}

acculturation, culture, social
The purpose of this study is to analyze the process of acculturation of student culture in social intercourse at campus UPP Tegal UNNES and Analyzing the obstacles faced by students in the process of cultural acculturation in social intercourse at campus UPP Tegal UNNES. The longterm goal is to find strategies or methods of student's cultural adaptation strategy which of course is different from the others. This research uses qualitative approach with case study type. The subjects of the study were all students of PGSD UPP Tegal UNNES. Informants students, lecturers, community Kemandungan and society Debong. Primary data sources are obtained through students because they know exactly about the process of cultural acculturation that takes place on campus. While secondary data sources obtained through reference with the study of cultural acculturation in society. Techniques of collecting data through interviews with informants, observations on campus sera student boarding environment and documentation. The validity of data is done by using source triangulation technique and method. Data were analyzed using Miles and Huberman model which include data collection, data reduction, data presentation and conclusion. Cultural acculturation is a social process that students pass through on campus as they associate with their friends. This process occurs because students have different cultures from each other. The process of meeting the two different cultures, but they are able to co-exist without eliminating the elements of each. They associate with college friends without distinguishing the origin of the region, tribe, religion and race. It can be seen through the activities undertaken on campus, such as student activities, activities in order to meet the tasks of college and so forth. In social intercourse they face obstacles, including language, customs and cultural differences.

\begin{abstract}
Abstrak
Tujuan dari penelitian ini adalah untuk menganalisis proses akulturasi budaya mahasiswa dalam pergaulan sosial di kampus UPP Tegal UNNES dan Menganalisis kendala yang dihadapi mahasiswa dalam proses akulturasi budaya dalam pergaulan sosial di kampus UPP Tegal UNNES. Tujuan jangka panjang adalah menemukan stategi atau metode strategi adaptasi budaya mahasiswa yang tentu saja berbeda dengan yang lain. Penelitian ini menggunakan pendekatan kualitatif dengan jenis studi kasus. Subyek penelitian adalah seluruh mahasiswa PGSD UPP Tegal UNNES. Informan meliputi mahasiswa, dosen, masyarakat Kemandungan dan masyarakat Debong. Sumber data primer diperoleh melalui mahasiswa karena mereka mengetahui persis mengenai proses akulturasi budaya yang terjadi di kampus. Sedangkan sumber data sekunder diperoleh melalui referensi berkenaan dengan kajian akulturasi budaya dalam masyarakat. Teknik pengumpulan data melalui wawancara dengan informan, observasi di kampus sera lingkungan kos mahasiswa dan dokumentasi. Validitas data dilakukan dengan menggunakan teknik triangulasi sumber dan metode. Data dianalisis menggunakan model Miles and Huberman yang meliputi tahap pengumpulan data, reduksi data, penyajian data dan penarikan simpulan. Akulturasi budaya merupakan proses sosial yang dilewati mahasiswa di kampus saat mereka bergaul dengan temannya. Proses ini terjadi karena mahasiswa memiliki kebudayaan yang berbeda satu sama lain. Proses bertemunya dua budaya yang berbeda, namun mereka mampu hidup berdampingan tanpa menghilangkan unsur masing-masing. Mereka bergaul dengan teman kampus tanpa membedakan asal daerah, suku, agama dan ras. Hal tersebut dapat dilihat melalui kegiatan yang dilakukan di kampus, misal kegiataan kemahasiswaan, kegiatan dalam rangka memenuhi tugas kuliah dan lain sebagainya. Dalam pergaulan sosial mereka menghadapi kendala, diantaranya bahasa, kebiasaan dan perbedaan kebudayaan.
\end{abstract}

(C) 2017 Universitas Muria Kudus
p-ISSN 2087-9385 e-ISSN 2528-696X
Alamat korespondensi:

Program Studi Pendidikan Guru Sekolah Dasar

Fakultas Keguruan dan Ilmu Pendidikan Universitas Muria Kudus

Kampus UMK Gondangmanis, Bae Kudus Gd. L. 1t I PO. BOX 53

Kudus

Tlp (0291) 438229 ex.147 Fax. (0291) 437198

E-mail: threeas_tuti@yahoo.com 


\section{PENDAHULUAN}

Mahasiswa Pendidikan Guru Sekolah Dasar (PGSD) Unit Pelaksana Program (UPP) Tegal berasal dari daerah yang berbeda. Mereka ada yang berasal dari Tegal, Brebes, Bumiayu, Pemalang, Batang, Kendal dan daerah lain. Berdasarkan observasi awal, lebih dari $50 \%$ mahasiswa berasal dari daerah luar Tegal. Mereka datang ke Tegal dengan membawa perbedaan budaya. Perbedaan yang sangat terlihat adalah bahasa, karena mereka menggunakan bahasa setiap hari dalam kehidupan sehari-hari. Setiap orang yang berasal dari daerah tertentu, pasti memiliki budaya yang tidak sama. Mulai dari kesenian, kebiasaan sampai pada adat yang tidak sama.

Mahasiswa memiliki perbedaan strategi adaptasi dalam pergaulan sosial di kampus dan lingkungan tempat kosnya. Model adaptasi sosial budaya mereka adalah dengan prinsip pragmatis. Mereka bersosialisasi di masyarakat jika ada kepentingan yang mendesak dalam rangka memenuhi kebutuhan sehari-ahri, misalnya membeli makanan, membeli pulsa dan lain sebagainya. Prinsip ini digunakan tentu saja karena ada alasan yang melatarbelakangi. Mereka tidak memiliki banyak waktu luang di kos, mereka sangat sibuk dengan urusan perkuliahan di kampus.

Mahasiswa PGSD Tegal, memiliki kebiasaan yang hampir sama dengan mahasiswa di PGSD Semarang. Salah satu kebiasaan tersebut adalah mereka sering pulang kampung saat weekend. Mereka merasa bahwa hari libur adalah hari khusus untuk bertemu dengan keluarga. Fenomena ini merupakan salah satu faktor kecil dari banyak faktor lain yang menjadi sebab mahasiswa tetap mempertahankan budaya mereka.

Akulturasi budaya yang terjadi di kampus PGSD UPP Tegal sangat kompleks. Rejeki (2007) menyatakan akulturasi adalah perpaduan budaya yang kemudian menghasilkan budaya baru tanpa menghilangkan unsur-unsur asli dalam budaya tersebut. Dalam perspektif komunikasi antar budaya, hal ini membutuhkan komunikasi agar tujuan tercapai.

Koentjaraningrat (2005) menjelaskan akulturasi adalah proses sosial yang terjadi bila kelompok sosial dengan kebudayaan tertentu dihadapkan pada kebudayaan asing yang berbeda. Syarat terjadinya proses akulturasi adalah adanya penerimaan kebudayaan tanpa paksaan, kemudian adanya keseragaman seperti nilai baru yang tercerna akibat keserupaan tingkat dan corak budayanya.

Dalam menjalin hubungan sosial di kampus, mahasiswa mengalami kontak sosial dengan sesama mahasiswa yang memiliki budaya berbeda. Misal ada mahasiswa yang berasal dari Batang, setiap hari dia komunikasi dengan orang Tegal atau orang pesisir Kulon lainnya. Tentu saja ia akan sangat berusaha untuk memahami budaya mereka.

Mahasiswa yang berasal dari luar Tegal masih mampu mempertahankan kebudayaan masing-masing, walau setiap hari terjadi kontak budaya. Budaya mempengaruhi kekuatan karakter (Seligman, 2002).

Mahasiswa tetap memiliki jati diri yang bagus. Mahasiswa tidak membentuk budaya sendiri, namun mereka bertahan tanpa terjadi konflik dalam kehidupan sehari-hari. Mereka menyadari bahwa perbedaan adalah sesuatu hal yang biasa dan harus dihargai, bukan untuk dipermasalahkan atau dijadikan sebagai alasan untuk bermusuhan satu sama lain.

\section{METODE PENELITIAN}

Penelitian ini menggunakan pendekatan kualitatif dengan jenis studi kasus. Hubungan peneliti dengan subyek penelitian bersifat netral karena peneliti tidak memihak pada salah satu subyek.

Subyek penelitian ini adalah seluruh mahasiswa PGSD UPP Tegal FIP Unnes. Informan meliputi mahasiswa, dosen, masyarakat Kemandungan dan masyarakat Debong. Mereka juga akan menjadi informan, walaupun tidak semuanya. Berdasarkan observasi awal, diperoleh data bahwa PGSD Tegal memiliki jumlah mahasiswa lebih dari 300 orang pada tahun 2017. Berdasarkan jumlah tersebut, peneliti perlu mengambil sampel untuk diteliti secara purposive (sesuai dengan kebutuhan) dan snowball.

Lokasi penelitian adalah kampus PGSD UPP Tegal FIP UNNES dan Daerah sekitar Kemandungan serta Debong yang menjadi tempat kos mahasiswa.

Sumber data dalam penelitian ini adalah Sumber data primer adalah seluruh mahasiswa PGSD UPP Tegal FIP UNNES. Untuk menguatkan data maka digunakan informan tambahan yaitu dosen, dan masyarakat sekitar kampus. Hal ini digunakan agar data lebih banyak dan mendalam, sehingga hasilnya juga valid. Sumber data sekunder meliputi buku-buku atau referensi yang relevan dengan tema penelitian.

Pengumpulan data dilakukan secara mendalam oleh peneliti agar data yang diperoleh lebih valid dan relevan dengan fokus penelitian. Pengumpulan data dilakukan melalui wawancara dan observasi. 
Observasi dilakukan untuk melihat peristiwa di kampus, misalnya saja bagaimana mahasiswa bergaul dengan temannya yang berasal dari Tegal di kampus, sementara mereka berasal dari daerah yang berbeda. Selain itu, peneliti akan melihat bagaimana cara mereka melakukan akulturasi budaya satu sama lain.

Teknik triangulasi yang digunakan adalah triangulasi sumber dan triangulasi metode.

Metode analisis data yang digunakan dalam penelitian ini adalah dengan menggunakan teknik deskriptif analisis kualitatif. Peneliti juga menggunakan proses analisis data Model Interaktif (Miles and Huberman, 2000: 20).

\section{HASIL DAN PEMBAHASAN}

Pada lapisan masyarakat manapun akan selalu ada proses sosial yang terjadi, baik proses asosiatif maupun disosiatif. Salah satu proses yang terjadi adalah akulturasi budaya. Hal tersebut dapat terjadi di lingkungan masyarakat kompleks maupun di kampus akibat adanya interaksi dan kontak sosial dengan manusia lain.

Akulturasi terjadi karena keragaman dalam masyarakat. Akulturasi budaya merupakan proses bertemunya dua kebudayaan atau lebih dalam suatu wilayah tertentu, lalu dua kebudayaan tersebut saling berinteraksi dan bergaul satu sama lain, namun budaya asli tidak hilang atau tidak saling mendominasi dalam arti yang negatif (Koenjaraningrat, 2005).

Salah satu fenomena yang terjadi adalah di kalangan mahasiswa PGSD UPP Tegal FIP UNNES. Dinamika di kampus sangat beragam. Mereka bergaul dengan teman kampus tanpa membedakan asal daerah, bahasa, agama dan ras. Mahasiswa mampu bekerjasama walau memiliki banyak perbedaan dan kekurangan.

Proses akulturasi budaya dapat dilihat di kalangan mahasiswa melalui beberapa kegiatan yang mereka lakukan dikampus, baik kegiatan kemahasiswaan maupun kegiatan dalam rangka menyelesaikan tugas perkuliahan. Kegiatan tersebut Pertama adalah Praktik Pengalaman Lapangan (PPL). Saat mereka semester 7, mereka melaksanakan PPL. Mahasiswa PGSD ditempatkan di Sekolah Dasar (SD) daerah Kota Tegal. Dalam satu sekolah latihan, ada 8-9 mahasiswa yang berasal dari rombel yang berbeda. Mereka diacak agar saling dapat berbaur. Tentu saja sebelumnya mereka hanya sebatas saling kenal saja, tidak akrab sama sekali. Di SD mereka harus bekerja tim agar PPL dapat berjalan dengan baik. Tugas demi tugas mereka kerjakan agar mendapat hasil maksimal di sekolah latihan. Berikut ini adalah gambar persiapan yang dilakukan mahasiswa saat sebelum terjun ke SD praktikan:

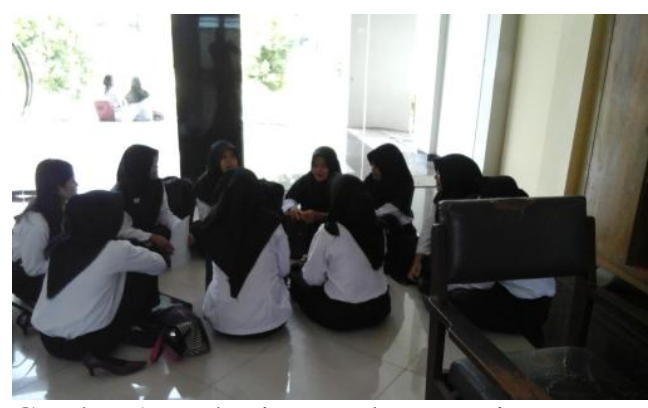

Gambar 1. Mahasiswa sedang persiapan PPL

Pada gambar 1 dapat dilihat mahasiswa semester 7 sedang membahas tentang segala keperluan PPL. Mereka merancang teknis waktu observasi awal ke SD, iuran untuk keperluan selama praktek dan diskusi mengenai teknik mengajar di SD. Hal ini mereka lakukan untuk membangun kekompakan diantaranya karena kurang lebih 3 bulan mereka akan bersama dan berkegiatan di SD.

Satu fenomena yang menarik terjadi di SD Margadana 07 Kota Tegal saat mahasiswa PPL. Ada 1 orang yang sering membolos, namun teman lain ikut menyemangati dan membantu dia agar dapat ujian PPL. Padahal awalnya mereka tidak 1 rombel. Mereka juga tidak berasal dari daerah yang sama. Asal daerah mereka adalah Brebes, Bumiayu, Kendal dan lain sebagainya. Perbedaan tersebut tentu saja membawa konsekuensi, diantaranya adalah perbedaan kebiasaan, budaya dan adat. Namun semua itu mampu mereka langgengkan masing-masing dalam pergaulan yang penuh dengan perbedaan.

Selain PPL, agenda kampus yang mengharuskan mereka kompak dan solid, misal ketika sedang pembelajaran di dalam kelas. Mereka harus mengerjakan setiap tugas dan soal yang diberikan bapak dan ibu dosen. Mahasiswa mampu beradaptasi dengan teman satu kelas di kampus. Mereka menjalin solidaritas tidak hanya diluar kampus, namun di dalam kelas juga. Walaupun perbedaan tetap menyelimuti mereka, misalnya dalam hal bahasa. Berikut ini merupakan cuplikan wawancara dengan mahasiswa asal Pati:

“..... Ketika bergaul di kampus saya tetap mempertahankan bahasa saya, yaitu penggunaan bahasa Pati. Walaupun teman-teman ada yang dari Tegal...."

Hal tersebut menjelaskan bahwa mahasiswa tetap mampu membaur dalam perbedaan, namun unsur budaya yang mereka bawa tidak hilang. Keduanya masih dapat 
dipertahankan dengan baik, walau mengalami sedikit kendala dalam pelaksanaannya. Ternyata bahasa tidak menjadi kendala berat. Mahasiswa mampu berprestasi. Mereka dapat membuktikan bahwa walaupun berbeda namun tetap satu tujuan. Hal tersebut seperti terlihat pada gambar sebagai berikut:

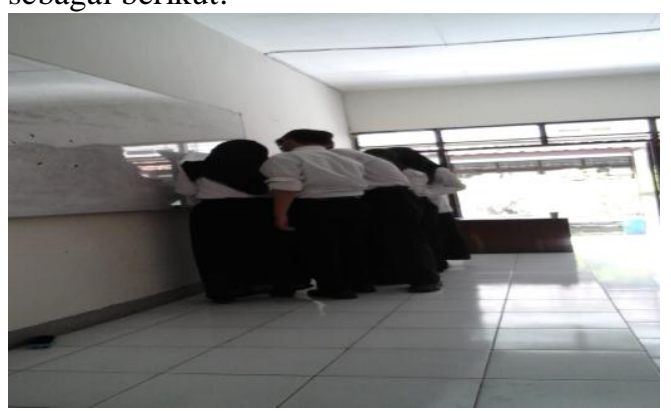

Gambar 2. Mahasiswa sedang kerjasama mengerjakan tugas dari dosen di depan kelas

Manusia merupakan mahkluk sosial, artinya mereka tidak dapat hidup sendiri namun harus berdampingan dengan manusia lainnya. Karena manusia sewaktu-waktu akan membutuhkan bantuan dari orang lain dalam menjalankan kehidupan. Salah satu contohnya yaitu jika ingin mencapai suatu tujuan tertentu manusia akan saling bekerjasama untuk mencapai tujuannya tersebut. Kerjasama bisa dilakukan dengan orang lain yang ada pada lingkungan sekitar. Misalnya orang orang yang ada di lingkungan kampus. Tentunya kerjasama bisa terbentuk karena adanya kepentingan yang sama salah satunya kepentingan untuk mencapai suatu tujuan. Selain kerjasama, juga diperlukan kontak sosial.

Kontak sosial pada seluruh lapisan masyarakat, sebagian masyarakat atau antar individu dalam dua masyarakat memiliki pengaruh besar karena seseorang melakukannya setiap hari. Pada dasarnya manusia selalu hidup membutuhkan orang lain. Walau dalam keterpaksaan mereka melakukan hal tersebut. Kontak budaya antara kelompok yang menguasai dan dikuasai dalam seluruh unsur budaya, baik dalam kebiasaan, bahasa dan lain sebagainya. Biasanya masyarakat yang menguasai adalah masyarakat asli atau pribumi, karena jumlah mereka lebih banyak. Sedangkan kelompok yang dikuasai adalah kelompok pendatang yang jumlahnya lebih sedikit atau minoritas. Dalam hal ini mahasiswa minoritas adalah mereka yang berasal dari Cilacap, Batang, Kendal dan daerah lainnya. Berikut ini adalah kegiatan mahasiswa dalam rangka berjuang dalam kompetisi nasional:

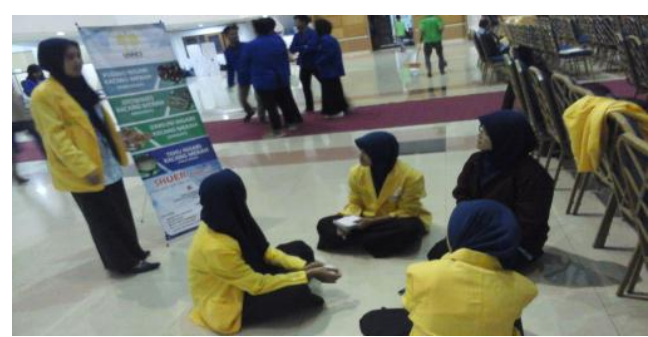

Gambar 3. Mahasiswa sedang latihan presentasi bersama sebelum menghadapi PIMNAS 2017

Pada gambar tersebut terlihat mahasiswa yang akan perlaga di Pekan Ilmiah Mahasiswa Nasional (PIMNAS) pada 22-28 Agustus 2017 di Universitas Muslim Indonesia Makassar. Mereka berasal dari daerah Tegal, Brebes, Pekalongan dan Pemalang. Penilaian mahasiswa yang berasal dari luar Tegal kepada orang Tegal adalah baik.

Alasan bahwa masyarakat Tegal merupakan masyarakat yang ramah juga diakui oleh mahasiswa. Berikut cuplikan keterangan mahasiswa asal Banjarnegara:

“... Orang Tegal itu baik-baik, ketika ada masalah, mereka sering membantu dalam banyak hal..."

Berdasarkan hal tersebut maka, dapat dijelaskan bahwa proses adaptasi budaya mahasiswa berjalan dengan baik. Mahasiswa sedang berdiskusi antar angkatan. Dalam gambar tersebut terlihat ada mahasiswa dan mahasiswi yang mempunyai budaya yang tidak sama. Budaya adalah suatu cara hidup yang berkembang dan dimiliki bersama oleh kelompok sosial, kemudian diwariskan dari generasi ke generasi. Budaya terbentuk dari banyak unsur yang rumit, termasuk sistem agama dan politik, adat istiadat, bahasa, bangunan, dan karya seni.

Proses pertemuan dua kebudayaan yang berbeda menyebabkan terjadinya akulturasi dan asimilasi (Poerwanto, 1997). Akulturasi terjadi ketika kelompok-kelompok individu yang memiliki kebudayaan yang berbeda berhubungan langsung dan intensif sehingga kemudian menyebabkan perubahan pola kebudayaan pada salah satu atau kedua kebudayaan tersebut. Akulturasi merupakan pertemuan suatu kebudayaan tanpa merubah ciri awal kebudayaan tersebut. Menurut Rapoport (1994), akulturasi merupakan salah satu bentuk kebudayaan berkelanjutan yang merupakan upaya suatu kebudayaan agar dapat bertahan. 


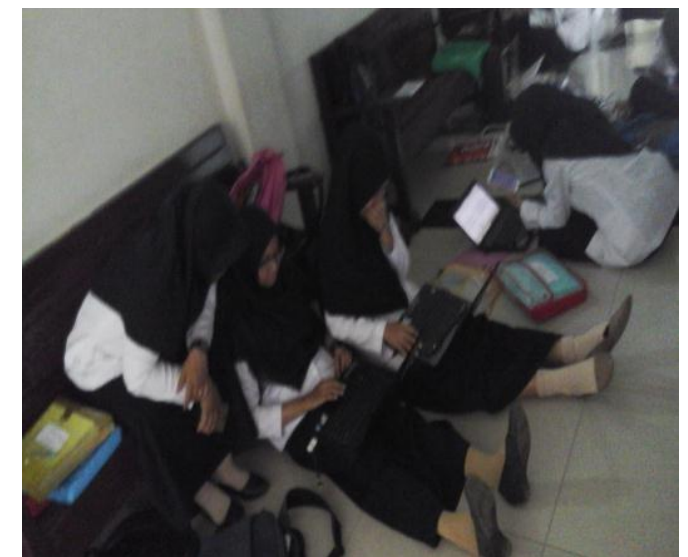

Gambar 4. Interaksi mahasiswa di kampus

Interaksi sosial merupakan suatu tindakan atau hubungan timbal balik yang dilakukan oleh seseorang kepada orang lain. Dalam interaksi terdapat suatu stimulus bagi tindakan individu lain yang menjadi pasangannya. Interaksi sosial dapat berjalan dengan baik ketika mereka memiliki persepsi yang sama dan sepaham. Pada dasarnya satu masyarakat dengan masyarakat lain memiliki budaya yang tidak sama, hal tersebut dipengaruhi oleh banyak faktor, diantaranya lingkungan alam. Misal budaya masyarakat pesisir cenderung kasar karena mereka tinggal sangat dekat dengan pantai sehingga ketika berbicara harus keras agar terdengar serta tidak kalah dengan ombak. Kendala yang Dihadapi Mahasiswa dalam Proses Akulturasi Budaya dalam Pergaulan Sosial di Kampus UPP Tegal UNNES adalah (1) Asal daerah, Diferensiasi asal daerah adalah pengelompokan manusia berdasarkan asal daerah atau tempat tinggalnya, di desa atau kota. Berdasarkan penggolongan ini dikenal dua kelompok masyarakat, yaitu masyarakat desa dan masyarakat kota. Masyarakat desa adalah kelompok orang yang tinggal di pedesaan atau berasal dari desa. Sedangkan masyarakat kota adalah kelompok orang yang tinggal di perkotaan atau berasal dari kota. Contoh diferensiasi asal daerah tampak dalam perilaku, tutur kata, cara berpakaian, cara menghias rumah, cara berinteraksi, dan lain- lain. (2) Bahasa, Bahasa adalah kemampuan yang dimiliki manusia untuk berkomunikasi dengan manusia lainnya menggunakan tanda, misalnya kata dan gerakan. Bahasa juga dapat diartikan sebagai alat untuk menyampaikan sesuatu yang terlintas di dalam hati. Bahasa merupakan alat untuk beriteraksi atau alat untuk berkomunikasi untuk menyampaikan pikiran, gagasan, konsep atau perasaan. (3) Kebiasaan, Kebiasaan adalah pengulangan sesuatu secara terus-menerus atau dalam sebagian besar waktu dengan cara yang sama. Kebiasaan mengulangi melakukan sesuatu yang sama berkali-kali dalam rentang waktu yang lama dalam waktu berdekatan. Hal tersebut merupakan keadaan jiwa yang mendorongnya untuk melakukan perbuatan-perbuatanya tanpa berpikir dalam.

\section{SIMPULAN}

Proses bertemunya beberapa kebudayaan di kampus, menyebabkan mereka memiliki hubungan pertemanan yang baik. Permasalahan yang dihadapai mampu mereka selesaikan dengan cara yang bijak. Hal ini karena kedua belah pihak memiliki kesadaran yang besar dalam saling memahami perbedaan. Pada dasarnya mereka berasal dari latarbelakang yang sama, namun mereka tetap mampu mempertahankan budaya mereka tanpa menghilangkan dan menggantikan dengan hal baru. Mereka tetap bangga dengan budaya yang dibawa dari daerah asal tempat tinggal.

\section{DAFTAR PUSTAKA}

Fardiyan, Ahmad Rudi. 2014. Rekayasa Konsumsi, Diferensiasi Sosial dan Konsumsi. Jurnal Sosiologi. 14 (1), hlm:59-68.

Geertz, Clifford. 1960. The Religion of Java. London: The university of Chicago Press.

Koentjaraningrat. 1984. Kebudayaan Jawa. Jakarta: Balai Pustaka.

, 2005. Pengantar Antropologi Budaya. Jakarta: Balai Pustaka.

Maryaeni, 2005. Metode Penelitian Kebudayaan. Jakarta:Bumi Aksara.

Moleong, Lexi. 2006. Metodologi Penelitian Kualitatif. Bandung : PT Remaja Rosdakarya.

Michael, Huberman. 2000. Analisis Data Kualitatif. Terjemahan Tjetep Rohendi Rohidi. Jakarta : UI Press.

Poerwanto, Hari. 1997. Manusia, Kebudayaan dan Lingkungan. Jakarta: Depdikbud.

Rapoport, Amos. 1994. Sustainability, Meaning \& Traditional Environment. IASTE Converence.

Rejeki, MC Ninik Sri. 2007. Perbedaan Budaya dan Adaptasi Antar Budaya dalam Relasi 
Kemitraan Inti Plasma. Jurnal Komunikasi. Vol. 4. No. 2: 145-166.

Seligman. 2002. Authentic Happines: Using the new positive psychology to realized your potential for lasting fulfillment. New York: Free press.

Subagyo, Joko. 2006. Metode Penelitian Kualitatif. Jakarta : PT Rineka cipta

Sugiyono. 2009. Metode Penelitian Kombinasi (Mixed Methods). Bandung: Alfabeta. 